\title{
Systems layouts with additional heat storages for low-temperature PVT collectors assisting Heat Pumps for DHW production
}

\author{
Francesca Martorana ${ }^{1, *}$, Marina Bonomolo $^{1}$, Giuliana Leone $^{1}$, Marco Beccali ${ }^{1}$, and \\ Biagio Di Pietra ${ }^{2}$ \\ ${ }^{1}$ Department of Engineering, University of Palermo, Palermo, Italy \\ ${ }^{2}$ ENEA - Dipartimento Unità per l'Efficienza Energetica (DUEE), Roma, Italy
}

\begin{abstract}
Systems based on the coupling of heat pumps (HP) with solar hybrid photovoltaic and thermal technology (PVT) for domestic hot water (DHW) production are a valid alternative to conventional electric production systems. In previous research, simulation models were developed in order to study the dynamic behaviour of a plant set-up based on the integration of an air-to-water heat pump aimed at DHW production with a rated power of $700 \mathrm{~W}$ and a storage tank of $500 \mathrm{lt}$. It was coupled with a plant of 6 PVT flat uncovered hybrid solar collectors with a peak power of $300 \mathrm{~W}$ for each module. Starting from the results obtained in the pre-sizing stage, in this study, a plant configuration was analysed to maximize the exploitation of the low-temperature contribution provided by the adopted PVT collectors. With this aim, the efficacy of the introduction of a solar water preheating storage in addition to the one normally integrated into the HP was investigated. Different operational scenarios have been studied to evaluate the best energy management strategies to be implemented. They consider the influence that the thermal capacity of the solar storage could have on the system performance according to its volume and the setpoint temperatures. The obtained results show that the proposed plant solution generally allows an increase in solar energy exploitation for DHW production and a reduction in HP electricity consumption.
\end{abstract}

Keywords: Heat pump, solar energy, thermal storage, renewable energy system; solar energy; PVT

\section{Nomenclature}

${ }^{\circ} \mathrm{C}$ : degrees Celsius

${ }^{\circ} \mathrm{CDB}$ : degrees Celsius (Dry Bulb)

A: Ampère

DHW: Domestic Hot Water

EES: Electric Energy Saving

$\mathrm{E}_{\text {grid: }}$ energy supplied by the grid

$\mathrm{E}_{\mathrm{HPWH}}$ : heat pump consumption

EнршнRES: energy consumed from the grid by the RES-based plants

$\mathrm{E}_{\mathrm{HPWH}} \mathrm{Std}$ : energy consumed from the grid by a conventional HPWH

$\mathrm{E}_{\mathrm{PV}}$ : electric energy supplied by the PV system

EPVT: electrical energy contribution from the RES plants

HPWH: Heat Pump Water Heater

IAM: The incidence angle modifier

K: Kelvin 
kWh: kilowatt-hour

1: liters

m: mass

$\mathrm{m}^{2}:$ meter square

mm: millimeters

PVT: Photovoltaic/Thermal

QDHW: thermal energy for DHW

$\mathrm{T}_{\mathrm{HPWH}}$ : temperature inside the heat pump storage

$\mathrm{T}_{\text {set: }}$ setpoint temperature

$\mathrm{T}_{\text {solar: }}$ : temperature reached inside the pre-storage tank

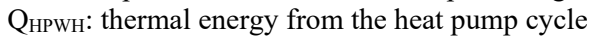

QDHWTground: heat demand for the production of DHW at $40^{\circ} \mathrm{C}$

ST: Solar Thermal

$\mathrm{T}_{\mathrm{a}}$ : the ratio between the HP electric energy consumption in a precise timeslot and the overall electricity consumption of the heat pump

V: Volt

W: watts

Wp: Watt peak

$\eta$ : electrical efficiency

$\eta_{0}$ : thermal efficiency

\section{Introduction}

During the last decades PVT technology is more and more widespread. One of the reasons is that they are safer and reliable and that the prices are more affordable following the collapse of photovoltaic costs. Even in situations in which the available area is limited, such as when the installation of systems is foreseen on the roofs of buildings, PVT collectors provide an attractive option.

In many studies present in literature, PVT collectors are an integral part of systems aimed at producing domestic hot water (DHW), often coupled to heat pumps (HP) and thermal storage tanks.

Mi et al. [1] proposed a novel hot water supply system based on PVT technology and a water source heat pump to improve the overall energy efficiency and capacity of the hot water supply system for a public bath in China. Del Amo et al. [2] investigated the technical and economic feasibility of a heating installation based on a PVT-assisted heat pump and including seasonal storage in an academic building at the University of Zaragoza. Wang et al. in [3] conducted a systematic review on the prevailing solar-assisted air heat pump (ASHP) systems. They found that PVT-ASHP systems can produce greater energy capacity if compared to other solar-assisted technologies. Additionally, users consume the lowest energy among the different solar ASHP systems analysed, as this system has maximum solar utilization.

The integration with thermal collectors, in general, leads to a decrease in the electrical consumption of the thermal machine and consequently increasing the overall performance of the system. Nevertheless, a correct integration has to be selected according to the PVT typology, heat pump source, and temperatures required by end uses.

Uncovered PVT collectors with increased heat transfer to ambient air can be suitable heat sources for heat pump systems. When the temperature in the heat pump's source is lower than the ambient temperature, the fluid can be heated up to ambient temperature even in periods without sunshine. The electric demand of the HP, which is reduced due to the lower temperature gaps, can be provided by the electric production of the PVT modules. This 
leads to a reduction in the amount of electricity absorbed by the electricity grid. For all these reasons, such integrations can be a valid alternative to traditional energy production systems. This option is easily available with water-to-water HPs. When air-to-water HPs are adopted, and PVT uses a liquid as heat carrier the thermal upgrade of HP source is not an easy task and not always effective according to the temperatures required for end uses. As reported also in [4], water-based PVT collectors fail to support the DHW requirement since it is required to deliver hot water at least at a temperature above $40{ }^{\circ} \mathrm{C}$, especially on cloudy days. In [5], in order to maximize the low-temperature contribution provided by the PVT collectors, an alternative plant configuration was investigated, and a novel PVTconcentrating system has been designed and developed to increase water outlet temperature.

In a previous study [6], the energy performance of a DHW system based on the integration of an air to water heat pump (HPWH) coupled to uncovered PVT panels with a sheet-andtube thermal absorber using water as heat transfer fluid has been investigated. The dynamic behaviour of the plant was analysed by running a series of simulations using the simulation software TRNSYS to test the performance of the entire system. In particular, it was considered the dependence on the specific performance of each component, and the load profile and environmental conditions. A set of different configurations was analysed. They were selected by varying the load profile and the number of the solar panels to size and optimize the energy consumption of the system. It was found that uncovered PVT collectors do not allow for significant benefits in direct hot water production due to the rather high average temperatures in the storage tank. This implies a low contribution of solar useful heat to DHW production.

Starting from the results obtained from this previous study, it was considered and studied the introduction of a sanitary water pre-heating tank dedicated to the exchange with the solar thermal circuit of the PVT system. The additional storage tank has the function of preheating the water coming from the aqueduct employing the solar thermal system. The main goal is to improve the thermal performance of the hybrid solar system while simultaneously reducing the need for the heat pump and, consequently, its electricity consumption. The present study, as well as [6], is part of a broader Research Cooperation Agreement between ENEA (National Agency for New Technologies, Energy and Sustainable Economic Development) and the Engineering Department of the University of Palermo and was preparatory to the design of an experimental plant set-up to be installed in the ENEA headquarters in Rome (Italy).

Several simulations have been hypothesized and simulated to analyse the performance of the proposed configuration plant for DHW production. Results show better exploitation of the thermal energy supplied by the PVT collectors and a sensible reduction of the HPWH electricity consumption.

\section{Case study description}

As said, the present study considers the system studied in precedent studies [6]. The plant includes six uncovered PVT panels manufactured by Fototherm (table 1) and an air-towater heat pump (table 2) dedicated to the production of DHW.

Table 1. Characteristics of PVT panels.

\begin{tabular}{|c|c|c|}
\hline Parameter & Value & Unit \\
\hline Dimensions & $\begin{array}{c}1660 \times 99 \\
0 \times 51\end{array}$ & $\mathrm{~mm}$ \\
\hline
\end{tabular}




\begin{tabular}{|c|c|c|}
\hline Aperture area & 1.58 & $\mathrm{~m}^{2}$ \\
\hline Number of cells & 60 & - \\
\hline Rated power & 300 & $\mathrm{Wp}$ \\
\hline Electrical efficiency $\eta$ & 18.3 & $\%$ \\
\hline \begin{tabular}{c} 
Thermal efficiency $\eta_{0}$ \\
\hline $\begin{array}{c}\text { Nominal thermal } \\
\text { power }\end{array}$
\end{tabular} & 58.3 & $\%$ \\
\hline $\begin{array}{c}\text { Fluid volume } \\
\text { Coefficient } \alpha 1\end{array}$ & 0.96 & 1 \\
\hline Coefficient $\alpha 2$ & 0 & $\mathrm{~W}\left(\mathrm{~m}^{2} \mathrm{~K}^{2}\right)^{-1}$ \\
\hline IAM K0 at $50^{\circ} \mathrm{C}$ & 96.0 & $\%$ \\
\hline
\end{tabular}

Table 2. Heat pump data sheet.

\begin{tabular}{|c|c|c|}
\hline Parameter & Value & Unit \\
\hline $\begin{array}{c}\text { Declared tapping } \\
\text { profile }\end{array}$ & XL & - \\
\hline $\mathrm{COP}$ & 3.06 & - \\
\hline $\begin{array}{c}\text { Parameter internal } \\
\text { unit }\end{array}$ & Value & Unit \\
\hline Tank water volume & 477 & 1 \\
\hline $\begin{array}{c}\text { Max. water } \\
\text { temperature }(\operatorname{tank})\end{array}$ & 85 & ${ }^{\circ} \mathrm{C}$ \\
\hline $\begin{array}{c}\text { Operating range } \\
\text { (DHW) Min. } \sim \text { Max. } \\
\text { External Temperature } \\
\quad \text { water side }\end{array}$ & $\begin{array}{l}2 \sim 35 \\
5 \sim 55\end{array}$ & $\begin{array}{l}{ }^{\circ} \mathrm{CDB} \\
{ }^{\circ} \mathrm{C}\end{array}$ \\
\hline Refrigerant type & R-410A & - \\
\hline $\begin{array}{c}\text { Parameter external } \\
\text { unit }\end{array}$ & Value & Unit \\
\hline $\begin{array}{c}\text { Operating range } \\
\text { (DHW) Min. } \sim \text { Max. }\end{array}$ & $-15 \sim 35$ & ${ }^{\circ} \mathrm{CDB}$ \\
\hline $\begin{array}{c}\text { Rated compressor } \\
\text { power }\end{array}$ & 700 & W \\
\hline $\begin{array}{l}\text { Electrical yearly } \\
\text { energy consumption } \\
\text { (average climatic } \\
\text { conditions) }\end{array}$ & 1368 & $\mathrm{kWh}$ \\
\hline $\begin{array}{l}\text { Electrical yearly } \\
\text { energy consumption } \\
\text { (cold climatic } \\
\text { conditions) }\end{array}$ & 1626 & $\mathrm{kWh}$ \\
\hline
\end{tabular}




\begin{tabular}{|c|c|c|}
\hline $\begin{array}{c}\text { Electrical yearly } \\
\text { energy consumption } \\
\text { (hot climatic } \\
\text { conditions) }\end{array}$ & 1247 & $\mathrm{kWh}$ \\
\hline
\end{tabular}

The novelty of this paper is the introduction in the system of a pre-accumulation tank of domestic water. It is characterized by a volume equal to the technical water tank integrated into the HPWH inside the hydraulic circuit (Figure 1).

This tank is located downstream of the aqueduct (water inlet point). It is connected to the solar thermal circuit with the aim of pre-heating the domestic water in a dedicated storage tank. According to the DHW demand, the water is then sent to the secondary side of the heat exchanger inside the HPWH tank in order to reach the setpoint temperature.

Thanks to three-way valves, the tank can be bypassed.

For a given setpoint of the water temperature (delivered to the end-user) $\left(\mathrm{T}_{\text {set }}\right)$, two operating modes have been tested:

1. ST-standard mode: when the temperature reached inside the pre-storage tank is higher than the temperature inside the heat pump storage $\left(\mathrm{T}_{\text {solar }}>\mathrm{T}_{\mathrm{HPWH}}\right)$ and higher than the setpoint temperature $\left(T_{\text {set }}\right)$, the heat pump is therefore bypassed and the entire system works like a traditional solar thermal system;

2. ST-preheating mode: when the temperature reached inside the pre-storage tank is lower than the temperature inside the heat pump storage $\left(\mathrm{T}_{\text {solar }}<\mathrm{T}_{\mathrm{HPWH}}\right)$ and lower than Tset the water is drawn to the HP circuit until it reaches the useful temperature for supplying the DHW at $\mathrm{T}_{\text {set }}$ (usually $40^{\circ} \mathrm{C}$ ).

It is necessary to underline that, in the above-described case, the cycle of the HP starts whenever the temperature of the storage tank is lower than the setpoint temperature $\left(\mathrm{T}_{\mathrm{set}}\right)$. 

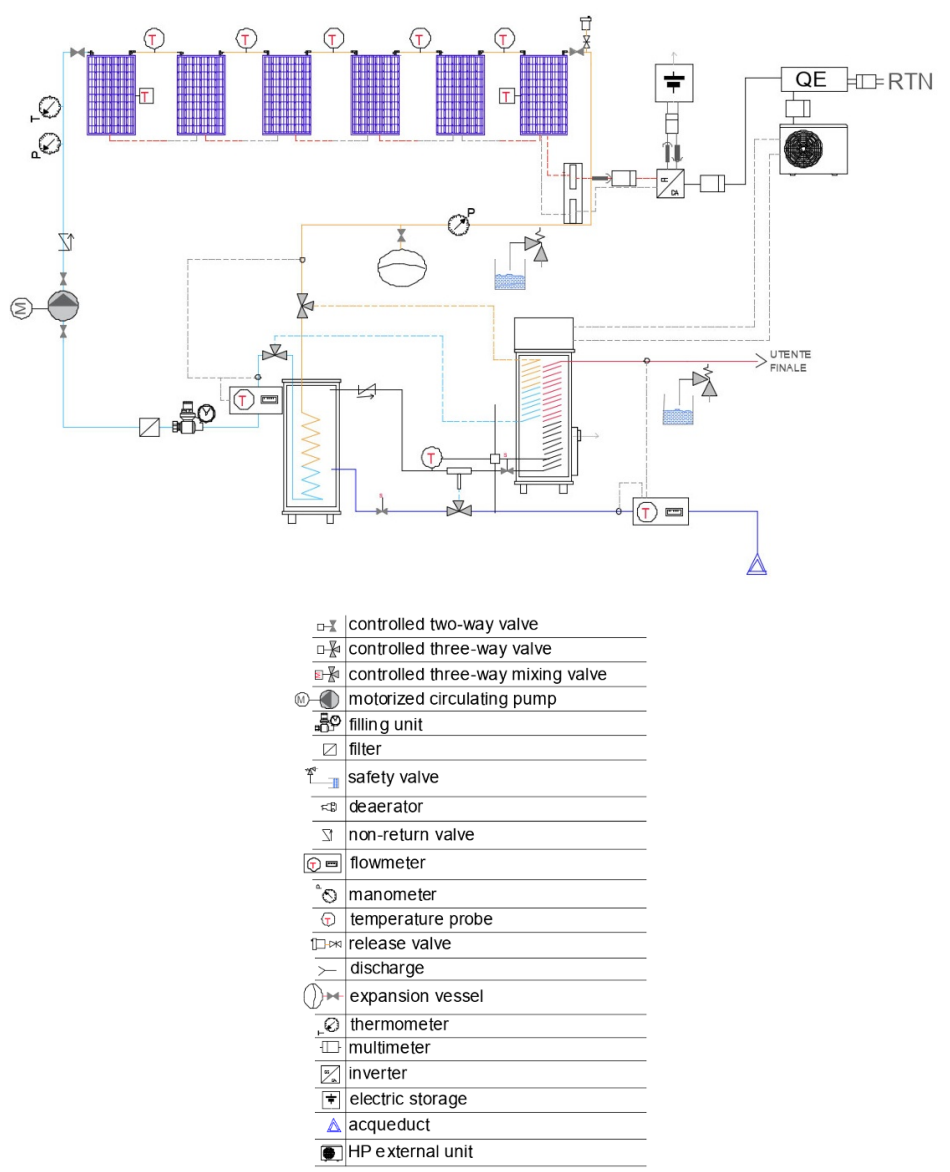

Fig. 1. System layout

\section{Methodology}

A dynamic model of the proposed system was implemented by using the TRNSYS simulation tool. Table 3 shows the types used: type 938 coupled to the type 1237 allows to simulate the behaviour of the specific HP; while type 560 was used to evaluate the producibility of the specific PVT panels. In both cases, the results achieved in operating conditions were validated by using the data presented in the manufacturer's datasheet. The same type 1237 (already validated) was used to simulate the thermal behaviour of the preheating tank.

Regarding the DHW hourly withdrawal profile, it was considered the standard XL profile $[7,8]$ by setting a daily consumption at $40^{\circ} \mathrm{C}$ (equal to 720 litres/day). This input data was simulated by means of types $11 \mathrm{a}$ and $11 \mathrm{~b}$. At the same time, type $48 \mathrm{~b}$ was added to the model. It simulates a $3000 \mathrm{~W}$ inverter system with an efficiency of 0.97 and a regulation 
efficiency of 0.84 . Similarly, type 47 a simulates the behaviour of a $10 \mathrm{kWh}$ electric storage system and an efficiency of 0.95 with a charge limit between $10 \%$ and $90 \%$ of the nominal value.

Table 3. TRNSYS Types (TESS Library).

\begin{tabular}{|c|c|}
\hline Component & TRNSYS type \\
\hline Heat Pump Water Heater & 938 (TESS) \\
\hline Thermal Storage Tank & 1237 (TESS) \\
\hline Water Heater Energy Supply & 1226 (TESS) \\
\hline PVT Panel & 560 (TESS) \\
\hline Pump & 3 \\
\hline Regulator Charge/Inverter & $48 \mathrm{~b}$ \\
\hline Electrical Storage Battery & $47 \mathrm{a}$ \\
\hline Weather Data Processor & 15 \\
\hline Differential controller & 1669 \\
\hline Thermostat & 2 \\
\hline Tempering Valve & $11 \mathrm{a}$ \\
\hline Diverter & $11 \mathrm{~b}$ \\
\hline
\end{tabular}

Finally, the types 1669,2 , and 11a were used to replicate the operating logics described in figure 2 . 


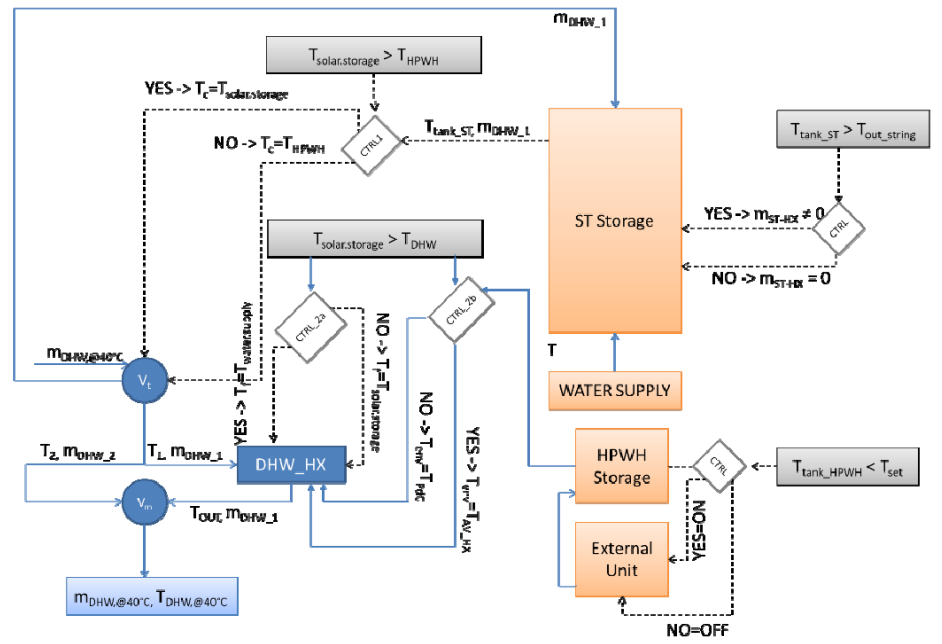

Fig. 2. Scheme of the TRNSYS model

For the purpose of this study, 3 main scenarios were analysed:

- Basic scenario (SC.0): the system without a pre-heating tank

- Pre-heating scenario: the system with 500-liter pre-heating tank on the solar thermal side:

- SC.A1 pre-heating setpoint temperature $\mathrm{T}_{\text {solar }}=35 \pm 2{ }^{\circ} \mathrm{C}$;

- SC.A2 pre-heating setpoint temperature $\mathrm{T}_{\text {solar }}=55 \pm 2{ }^{\circ} \mathrm{C}$.

In both cases SC.A1 and SC.A2, according to the HPWH operating limits, the heat pump tank set-point temperature is assumed equal to $45 \pm 2^{\circ} \mathrm{C}$. It results in the fact that with Scenario A.1, the operation in pre-heating mode during $24 \mathrm{~h}$ is the most probable mode. On the other hand, given the higher temperatures available in the pre-heating stage in Scenario A.2, both "standard" and "pre-heating mode" are to be investigated.

A set of indices were introduced to assess how the system meets the thermal and electrical demand.

The first two are: the solar thermal $\left(\mathrm{SF}_{\mathrm{th}}\right)$ and electrical $\left(\mathrm{SF}_{\mathrm{el}}\right)$ fractions and are evaluated as follows:

$$
\begin{aligned}
& S F_{\mathrm{th}}=Q_{\mathrm{PVT}} /\left(Q_{D H W, \text { Tground }}\right) \\
& S F_{\mathrm{el}}=E_{\mathrm{PVT}} /\left(E_{P V T}+E_{G R I D}\right)
\end{aligned}
$$

where QPVT and $E_{P V T}$ respectively represent the contribution of thermal and electrical energy provided by the solar PVT system, while QDHw,Tground is the heat demand for the production of DHW at $40^{\circ} \mathrm{C}$. It is a function of the temperature of the water entering the system (variable between the system proposed with/without pre-heating). $\mathrm{E}_{\mathrm{GRID}}$ is the electricity taken from the grid. 
Therefore, the electric energy saving (EES) was introduced. It is assessed by the ratio between the energy consumed from the grid by a stand-alone HP $\left(\mathrm{E}_{\mathrm{HPWH}}\right)$ and the energy consumed from the grid by the solar assisted HP ( $\left.\mathrm{E}_{\mathrm{HPWH}-\mathrm{RES}}\right)$ :

$$
E E S=1-E_{\mathrm{HPWH}-\mathrm{RES}} / E_{H P W H}
$$

Simulations have been run for the climate of Rome, Italy.

\section{Results}

Regarding the thermal and electrical producibility of the PVT string in Scenarios A.1 and A. 2 compared to SC. 0 , as expected, the pre-heating system has allowed greater yearly useful heat production (up to 4 times in SC.A1, and 5.6 in SC.A2 greater than the basic system). The increase in useful heat production allows a decrease in the temperature of the photovoltaic cells. It provides an increase in photovoltaic production of about $3 \%$ on an annual basis, without substantial differences between SC.A1 and SC.A2. The increase in solar production in both Scenarios A has also allowed a reduction in the electricity consumption of HPWH (Figure 3).

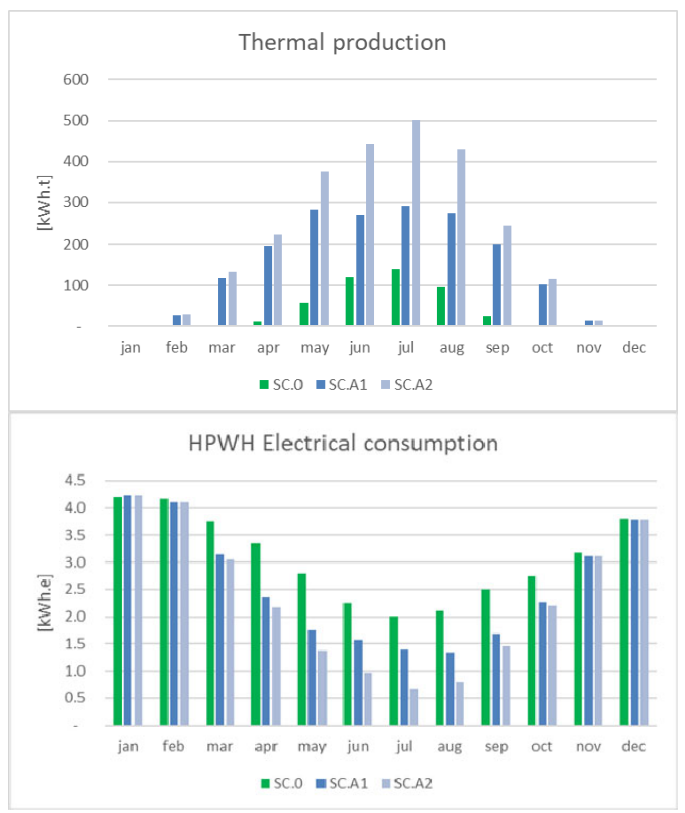

Fig. 3. Comparison of baseline scenario and SC.A1 e SC.A2 scenarios

As shown in figure 3, the electrical and thermal consumption profiles were analysed for a typical day of the month with an irradiation value close to the median of the monthly values (3.7 kW / $\mathrm{m}^{2}$ day, March). It is a useful analysis being a hybrid PVT system. For the SC.0 scenario, there is zero solar thermal production; while in the case of Scenarios A, there is a 
solar thermal production equal to 3.0 and $3.3 \mathrm{kWt}$, respectively for the SC.A1 and SC.A2 Scenarios (Figure 4).

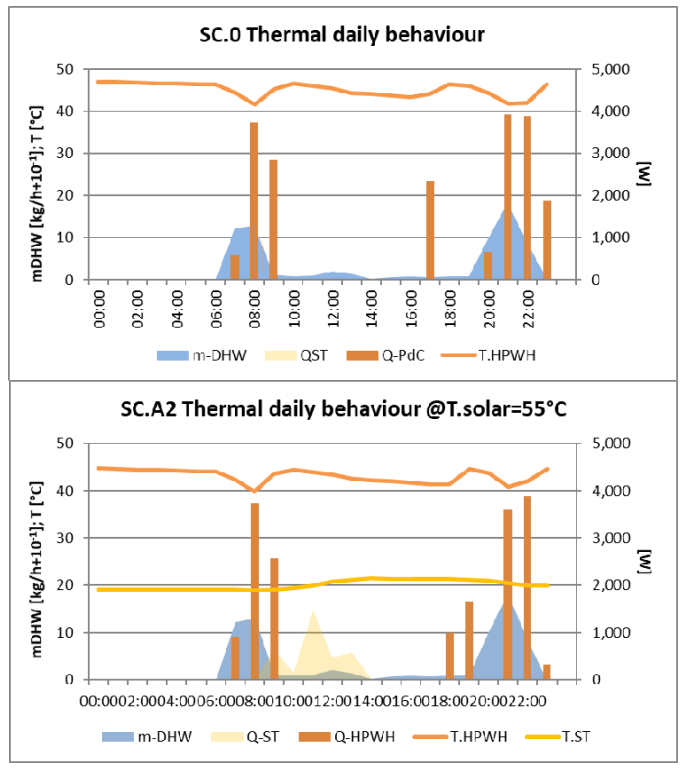

Fig. 4. Analysis of the system's electricity consumption on a typical day in intermediate seasons

On the chosen day, Scenario SC.0 and SC.A are different as well from an electrical point of view. It should be noted that the state of charge of the battery (SOC) in the SC.0 is insufficient to cover the electricity requirement during the first hours of the day. Consequently, some consumption from the grid is recorded in SC.0.

Indeed, even if some thermal production in SC.A is recorded during January and February, it is not still enough to influence the thermal behaviour of the whole system. Consequently, the electricity consumption by the heat pump is actually the same both in SC.0 and SC.A (Figure 5). On the other hand, during these months the available energy from the PV system does not ensure the energy self-sufficiency for the HPWH even including the electrical storage effect: the SOC of the battery generally drops down close to the minimum allowed charge in the evening $(720 \mathrm{Wh})$.

So that, in the chosen day and in the SC.0 Scenario, the initial state of charge is still insufficient to match the electricity demand in the early hours of the day (in the absence of sufficient PV production). Consequently, it should be necessary to draw electrical energy from the grid. From April the two main scenarios (SC.0 and SC.A) allow energy selfsufficiency. 


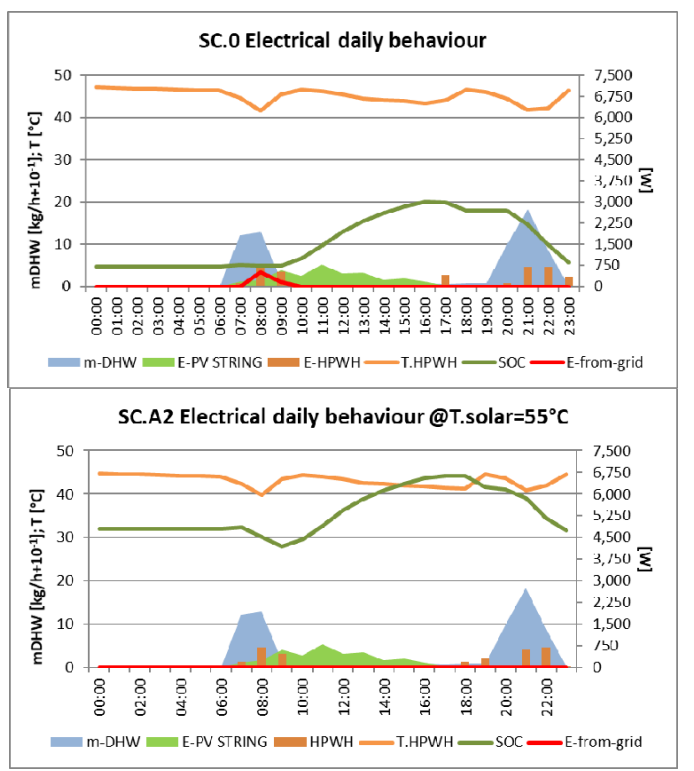

Fig. 5. Analysis of electricity consumption of the system on a typical day in the winter seasons

Finally, it is useful to highlight the influence of the set-point temperature assumed for the pre-heating storage management. An analysis has been performed for a typical day in the month of greatest solar irradiation for the location under study ( $\left.200 \mathrm{kWh} / \mathrm{m}^{2} \mathrm{July}\right)$. If there are not significant DHW withdrawals, the thermal energy produced during the day continues to be stored in the solar tank and used during the evening. On a typical day and for the chosen withdrawal time profile, the daily electricity consumption of the HPWH increased by $38 \%$ (Figure 5) by limiting the temperature of the pre-storage tank to $35^{\circ} \mathrm{C}$. In all scenarios, electricity consumption is in any case covered by the PV/battery system. 


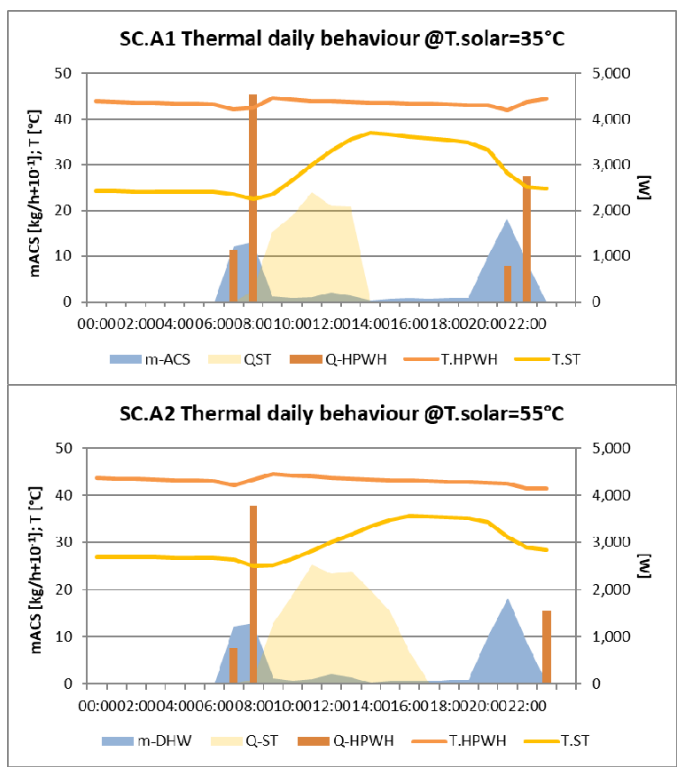

Fig. 6. Analysis of the thermal consumption of the system in the typical summer day

Finally, the reduction of the heat to be provided by HPWH. It was assessed according to the temperature of the water entering the heat exchanger $\left(\mathrm{T}_{\mathrm{in}}=\mathrm{T}_{\text {acquedoto }}\right.$ in the case SC.0 and $\mathrm{T}_{\mathrm{in}}=\mathrm{T}_{\mathrm{ST}}$ in the case of SC.A). Consequently, a decrease in the electricity consumption (Figure 6) has been calculated. With the same heat demand for DHW, there was a reduction in heat demand between Scenarios SC. A and SC.0 equal to about 35\% and a consequent reduction in electricity consumption equal to an average of $21 \%$, in the presence of the preheating storage.

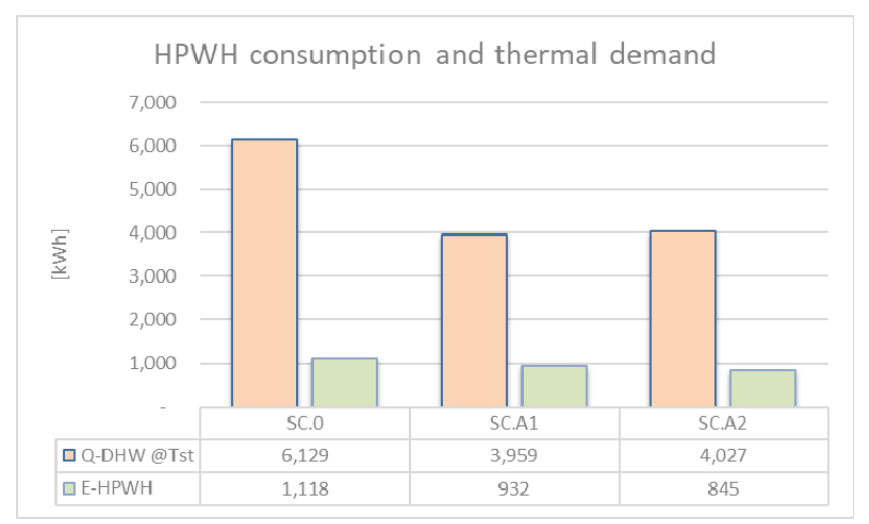

Fig. 7. HPWH consumption analysis 
As reported in Figure 7, the lower the heat demand of the HP, the higher the $\mathrm{SF}_{\text {th }}$ index. It is expressed as the ratio between the production of the ST system and the demand for DHW at $40^{\circ} \mathrm{C}$. This latter was evaluated considering the lower temperature of the water. In particular, the $\mathrm{SF}_{\text {th }}$ calculated for the two scenarios SC.A1 and SC.A2 are higher than the $\mathrm{SF}_{\text {th }}$ calculated for SC.0 respectively of the $14 \%$ and of the $20 \%$.

Finally, the $\mathrm{SF}_{\mathrm{el}}$ index and the EES index for each scenario show how the photovoltaic system is able to meet the electricity consumption of the HP regardless of the system chosen (always greater than 70\%). As shown in Figure 8, it is possible to note that there are slight differences between the values obtained individually in each scenario due to the different reference points (consumption of the HP).

It should be noted that the consumption (in absolute value) from the grid decreased from $283 \mathrm{kWh}$ for the SC.0 scenario to 256 for both the SC. A scenario $(-10 \%)$. As already highlighted in Figure 5, the photovoltaic production is almost the same (approximately $1670 \mathrm{kWh}$ per year). On the other hand, the energy fed into the grid (without accounting for the amount stored) is reduced from $820 \mathrm{kWh}$ for the SC.A2 Scenario to $510 \mathrm{kWh}$ for the SC.0 Scenario.

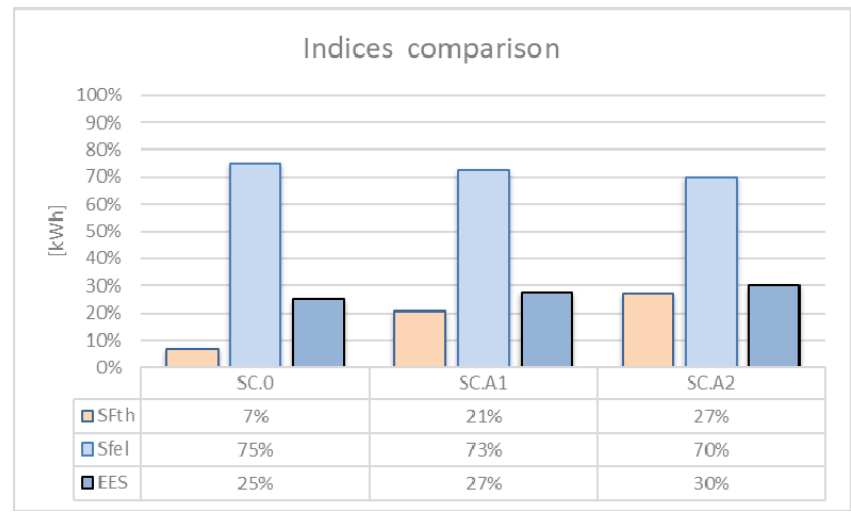

Fig. 8. - Indices comparison for the three scenarios

\section{Conclusions}

This study presents a development of previous research carried out as part of the collaboration between the University of Palermo and ENEA (in the framework of the Research of the Electric System programme). It concerned the energy analysis of a DHW production plant powered by a heat pump integrated with an uncovered PVT system. Two systems solutions were hypothesized. In the first one, the solar thermal circuit was connected to the heat exchanger placed inside the technical water storage of the HPWH itself (basic scenario); in the second one, the same circuit was connected to a DHW preheating tank. It has been found that the introduction of a thermal pre-storage tank and correct management of it, has allowed a better operation in terms of useful heat production compared to a direct connection of the solar circuit with the heat pump tank. This thermal contribution allows to reduce the energy demand required by the heat pump $(-35 \%$ compared to the base scenario) and to consequently reduce its consumption $(-20 \%$ on average). The increase in solar thermal production has also resulted in an increase in electrical producibility of about $3 \%$ thanks to the reduction in the temperature of the cells 
due to the operation of the PVT itself. In general, photovoltaic production proved to be sufficient to cover over $70 \%$ of the annual consumption of HP in all the cases analysed.

\section{References}

1. P. Mi, L. Ma, J. Zhang, Integrated optimization study of hot water supply system with multi-heat-source for the public bath based on PVT heat pump and water source heat pump. Applied Thermal Engineering, 176 : 115146. (2020)

2. A. Del Amo, A. Martìnez-Gracia, T. Pintanel, A. A. Bayod-Rùjula, S. Torné, Analysis and Optimization of a Heat Pump System Coupled to an Installation of PVT Panels and a Seasonal Storage Tank on an Educational Building. Energy and Buildings, 226: 110373. (2020)

3. X. Wang, L. Xia, C. Bales, X. Zhang, B. Copertaro, S. Pan, J. Wu, A Systematic Review of Recent Air Source Heat Pump (ASHP) Systems Assisted by Solar Thermal, Photovoltaic and Photovoltaic/Thermal Sources. Renewable Energy, 146: 2472-87. (2020)

4. S. Vaishak, and V. B. Purnanand, Photovoltaic/Thermal-Solar Assisted Heat Pump System: Current Status and Future Prospects. Solar Energy 189: 268-84. () https://doi.org/10.1016/j.solener.2019.07.051.

5. L. Kumar, M. Hasanuzzaman, N. A. Rahim, M. M. Islam, Modeling, simulation and outdoor experimental performance analysis of a solar-assisted process heating system for industrial process heat. Renewable Energy, 164, 656-673. (2021)

6. F. Martorana, M. Bonomolo, G. Leone, F. Monteleone, G. Zizzo, M. Beccali, SolarAssisted Heat Pumps Systems for Domestic Hot Water Production in Small Energy Communities. Solar Energy 217: 113-33. (2021)

7. UNI EN 12831-1:2018-Prestazione energetica degli edifici - Metodo per il calcolo del carico termico di progetto - Parte 1: Carico termico per il riscaldamento degli ambienti, Modulo M3-3

8. COMMISSION REGULATION (EU) No 814/2013 of 2 August 2013 implementing Directive 2009/125/EC of the European Parliament and of the Council with regard to ecodesign requirements for water heaters and hot water storage tanks. 